\title{
Observations on the nutritive value of traditionally ground cereals in Southern Rhodesia
}

\author{
BY W. R. CARR \\ Government Analyst's Laboratory, P.O. Box 8042, Causeway, Salisbury, \\ Southern Rhodesia
}

(Received 20 September r960-Revised 7 March I96r)

The increase in the number of power-driven hammer-mills in the rural areas of Southern Rhodesia is causing a rapid reduction in the amount of grain ground by women in the villages, except in the remoter areas, where the main crop is usually sorghum or millet.

The meal produced by hammer-mills is substantially straight-run and is usually modified slightly by sifting before cooking, the coarser, branny particles being given to livestock. On the other hand, the traditional method of grinding produces a meal of a low extraction rate, particularly with the most important crop, maize. In a country where $80 \%$ or more of the calories come from cereals, the new method of grinding must cause an appreciable change in the nutritive value of the diet. The traditional methods of grinding were therefore investigated to establish the amounts of calcium, phosphorus, iron, thiamine, riboflavin and proximate constituents in foods ground in that way.

There appear to have been few such studies elsewhere in Africa. Williamson (I955) describes methods used in Nyasaland and refers to the work of Scott in Tanganyika, but no analytical figures are given. Recently, Ellis (1959) has given some figures for Nyasaland and indicated that the African's preference for flint maize is justified.

EXPERIMENTAL

\section{Traditional grinding implements}

The implements used are the same in all areas and are (the African names are given in the Shona dialect):

Pestle and mortar. The pestle (muUtsi) and the mortar (dure) are both carved from hardwood, such as the mopane (Colophospermum mopane Kirk ex J. Leonard) and the mukwa (Pterocarpus angolensis DC.). The pestle is a pole about $120 \mathrm{~cm}$ long with a rounded bottom (garo) and a pointed top (muno, nose). The bottom is used for stamping larger, damper particles and the top for finer and drier particles.

The mortar is carved out of one block of wood and is often decorated in relief externally. It is usually about $40-50 \mathrm{~cm}$ in internal diameter, tapering inside to a point into which the top of the pestle will fit.

Grinding stones or quern. These consist of selected granite rocks. The main stone (guyo) is often about $50 \mathrm{~cm}$ long and $25 \mathrm{~cm}$ wide; it is carefully selected to be not so 
thick as to make it unwieldy, and one end is supported on another stone so that it is at a slight angle to the ground. The small stone (huyo) is large enough to be held in both hands, and has a rounded top and a flat bottom for conveniently rubbing over the larger stone. The main stone is slightly hollowed and the hollow increases with use until it becomes too deep and the stone is finally discarded. This quern is similar to those used in ancient Egypt from 4000 to 2000 B.C.

Winnowing basket. The winnowing basket (rusero) is a closely woven circular basket about $70 \mathrm{~cm}$ in diameter and $7 \mathrm{~cm}$ deep. It has a slightly concave bottom and is used skilfully by the women at various stages of the grinding to separate off the coarser and lighter branny particles of the grain, which they do by tossing the grain with the basket held at a slight angle.

\section{Methods of grinding}

Although grinding methods vary in detail from area to area, the main principles are the same throughout the country, and a description is given here of the complete process for different cereals as it was observed in specified areas.

Maize (Zea mays L.) (Kandeya Reserve, Mount Darwin; tribe, $m$ Korekore). This is by far the most important of the cereals, and the main crop consists of white dent varieties. A suitable quantity of the stored grain was placed in the mortar, and to it about $10 \%$ by weight of water was added. The mixture was then stamped with the bottom of the pestle until most of the outer portions of the grain were removed, and the pounded mixture was mostly in the form of grits. The pestle was then reversed, and the stamping was continued for a short time. The resulting mixture of grits, outer coating and meal was emptied on to a winnowing basket and winnowed until most of the coarser branny particles were removed. The winnowings were discarded to be eaten by the small livestock of the village. Only in times of extreme food shortage would these offals be used in the human diet. The remainder was returned to the mortar for a short period and restamped and rewinnowed. The grits were then soaked overnight with an excess of water in a gourd, and on the following morning the supernatant water was poured off and the mixture kneaded briefly with fresh water, which was also discarded. The damp grits were then sun-dried for 5-Io min, spread out on a winnowing basket, which also acted partly as a filter. The pestle and mortar were commonly washed out with the water from this second washing before the grits were stamped with the top of the pestle.

The resulting meal was then sifted into a winnowing basket through a fairly fine sieve, and the retained particles were returned to the mortar. The stamping and sifting procedure was repeated until a small amount of coarse particles was left, and these were ground on the quern and sifted, the remnants (about $20 \mathrm{~g}$ from $\mathrm{I} \cdot \mathrm{I} \mathrm{kg}$ of grain) being discarded.

The addition of water makes it rather difficult to determine the extraction rate, as both the winnowings and final meal contain about $35 \%$ moisture. However, the values for the final products were converted to a basis of $10 \%$ moisture and the figures obtained, based on the amount of grain placed in the mortar at the beginning, were: meal 55 , offals 33 and waste (i.e. material lost in the grinding processes) $12 \%$. 
Kaffir corn (mapfunde)(Sorghumvulgare Pers.)(Chinyika Reserve; tribe, mZezuru). A good quality of red sorghum was supplied to the villagers in this community, which is predominantly maize-growing. The grain was placed in the mortar with about $20 \%$ of its weight of water, stamped with the bottom of the pestle for about 20 min, winnowed and restamped. The stamping was finished with the top of the pestle. The pounded grain was washed with water and placed on a fine sieve to drain. It was laid out on a tin tray to dry for about ro min and slightly roasted in a pan to make further grinding easier. It was then ground on the quern and sifted through a fine sieve, the coarser particles being winnowed and reground. This final process was repeated until a small quantity remained on the sieve; it was discarded and given with all the offals to the small livestock. The offals contained $36 \%$ and the final meal $15 \%$ moisture; when converted to a $10 \%$ moisture basis the proportions yielded by the grain placed in the mortar were: meal 66, offals 29 , and waste $5 \%$.

Finger millet (rapoko) (Eleusine coracana) (Chinyika Reserve; tribe, mZezuru). The grinding of rapoko was considerably simpler than that of maize or kaffir corn. Water was not used, and the grain merely ground in the pestle and winnowed, or sometimes sifted, winnowed and reground. This process resulted in a distribution, based on the weight of grain taken originally, of: meal 80 , offals 18 and waste $2 \%$.

It should be pointed out that rapoko is used mainly for brewing and is not commonly ground to a meal to make thick porridge ( $s a d z a)$.

Bulrush millet (munga) (Pennisetum typhoideum) (S.E. Sabi Reserve; tribe, va Karanga). The grain was placed in the mortar, and about $20 \%$ of its weight of water was added; the stamping was similar to that for sorghum. The grain was winnowed, lightly roasted, and finally ground on a quern as with sorghum, although no sieve was used. The extraction rate for munga was $75 \%$.

\section{Analytical methods}

After thorough mixing, the samples were taken at the grinding site in Polythene bags or fruit jars, and the analysis was begun as soon as practicable. The specimens with high moisture content were sampled for the determination of moisture, and were then spread out as thin layers in a stream of warm air until the moisture content dropped to about $10 \%$. Subsequent analysis was made on the air-dried material.

Moisture. Samples of about $2 \mathrm{~g}$ were accurately weighed and dried for $4 \mathrm{~h}$ at $100^{\circ}$.

Nitrogen. The Kjeldahl method was used with mercury-catalyst tablets (British Drug Houses Ltd). After digestion, $50 \%(\mathrm{w} / \mathrm{v})$ sodium-hydroxide solution, containing $5 \%(\mathrm{w} / \mathrm{v})$ sodium thiosulphate, was added, and the released ammonia was distilled into boric acid $(4 \%, \mathrm{w} / \mathrm{v})$ and titrated with standard acid solution.

Fat (total lipids). An acid-hydrolysis method described by Kent-Jones \& Amos (1947) was used.

Crude fibre. The method was that laid down for feeding-stuffs by The Fertilizers and Feeding Stuffs Regulations (Great Britain, Parliament, 1932).

Ash. Samples of about $2 \mathrm{~g}$, accurately weighed, were ignited to constant weight at a temperature of less than $500^{\circ}$.

Mineral constituents. $\mathrm{Ca}, \mathrm{P}$ and $\mathrm{Fe}$ were determined on samples of solution prepared 
from the ash as previously described (Carr, 1956), except that the analysis for $\mathrm{Ca}$ was completed by the method of Gehrke, Affsprung \& Yung (1954) and for Fe by that of Bandemer \& Schaible (1944).

Thiamine. The vitamin was extracted and purified as described by the Association of Vitamin Chemists Inc. (195 I); it was oxidized to thiochrome and measured in a photofluorimeter by the method of Ridyard (1949).

Riboflavin. The standard fluorimetric method of the Association of Vitamin Chemists Inc. (I95I) was used.

\section{RESULTS}

The composition of meal and offals from maize, sorghum and bulrush millet is shown in Table I. For finger millet, because of the small losses of the grinding processes, the values are given for whole grain and meal. Except for moisture, the results are expressed on the dry basis because of the wide variation in moisture content.

Table r. Proximate composition and calcium, phosphorus, iron, thiamine and riboflavin content of meals prepared from grains ground in the traditional way in Southern Rhodesia

(Except for moisture, values are given per roo g dry material)

Moisture (g/100 g)

Nitrogen (g)

Fat (total lipids) (g)

Carbohydrate (by difference)

(g)

Crude fibre (g)

Ash (g)

$\mathrm{Ca}(\mathrm{mg})$

$\mathrm{P}$ (mg)

$\mathrm{Fe}$ (mg)

Thiamine (mg)

Riboflavin (mg)

\begin{tabular}{|c|c|c|c|c|c|c|c|}
\hline \multicolumn{2}{|c|}{ Maize } & \multicolumn{2}{|c|}{ Sorghum } & \multicolumn{2}{|c|}{ Pennisetum } & \multicolumn{2}{|c|}{ Eleusine } \\
\hline Meal & (nfolo & Meal & Offals & Meal & Offo & M & Whole \\
\hline & & & & & & & \\
\hline $34 \cdot 2$ & 34.0 & 15.4 & $36 \cdot 0$ & $16 \cdot 0$ & $24 \cdot 6$ & 13.0 & II 9 \\
\hline $\mathrm{r} \cdot 38$ & $I \cdot 78$ & I 88 & $I \cdot 90$ & $I \cdot 22$ & $2 \cdot 11$ & $I \cdot 20$ & $\mathrm{I} \cdot \mathrm{I} 7$ \\
\hline$I \cdot 5$ & $12 \cdot 4$ & $3 \cdot I$ & $6 \cdot 6$ & $4 \cdot 2$ & $x I \cdot 6$ & $2 \cdot 3$ & $2 \cdot 2$ \\
\hline $89 \cdot 3$ & $68 \cdot 5$ & $82 \cdot 3$ & $76 \cdot 6$ & $84 \cdot 1$ & 6277 & 83.5 & $84 \cdot 7$ \\
\hline 0.3 & $4 \cdot 7$ & 0.7 & $2 \cdot 9$ & 0.7 & $8 \cdot 1$ & 3.3 & $3 \cdot I$ \\
\hline 0.29 & $3 \cdot 30$ & 3.02 & $2 \cdot 84$ & $3 \cdot 88$ & $5 \cdot 26$ & $3 \cdot 85$ & $3 \cdot 23$ \\
\hline 7 & $2 \mathrm{I}$ & I6 & $4 I$ & 20 & 50 & 300 & 300 \\
\hline 46 & 580 & 176 & 373 & 202 & 631 & 220 & 245 \\
\hline 5 & 22 & 18 & 13 & 46 & 34 & 35 & I I \\
\hline 0.04 & 0.75 & $0.3 \mathrm{I}$ & 0.67 & 0.22 & 0.50 & 0.34 & 0.36 \\
\hline 0.02 & 0.31 & 0.06 & 0.18 & 0.26 & $0.5 \mathrm{I}$ & 0.16 & 0.19 \\
\hline
\end{tabular}

\section{DISCUSSION}

The analytical figures show clearly that traditional grinding methods tend to give highly refined products with concomitant losses of important nutrients. On this basis, it appears that a change to mechanical milling should lead to a considerable improvement in the nutritive value of the diet of Africans living in rural areas, for the main cereal, maize, shows by far the highest losses during the traditional wet milling method. The results also indicate the importance of establishing the true nutrient content of the ground cereal eaten in rural African areas before beginning dietary surveys, since otherwise a totally false impression of the intake of nutrients may be obtained.

Maize offals have a higher concentration than maize meal of all constituents except carbohydrate and moisture. Values for thiamine and riboflavin obtained on local straight-run and whole-grain maize were 0.4 and $0.1 \mathrm{mg} / \mathrm{I} 00 \mathrm{~g}$ respectively, indicating that only $10-20 \%$ of these vitamins were retained in the traditionally prepared 
meal. Considerable amounts of fat, fibre and mineral matter had been lost, and the protein content was much lower than the 10\% to be expected in dry, whole grain.

The losses from sorghum meal were not so great as from maize. The thiamine and riboflavin content of a sample of whole grain used in the grinding was found to be 0.53 and $0.12 \mathrm{mg} / \mathrm{ro0} \mathrm{g}$ respectively, indicating a loss of about $50 \%$, but there was always an increase in $\mathrm{Fe}$ when the quern was used in the grinding process. The stones used obviously have a fairly high Fe content, as indicated by their slight reddish tinge.

Much smaller loss occurred in bulrush millet and the high extraction rate of finger millet resulted in a negligible difference between the grain and the meal.

The composition of the final product will undoubtedly vary with the ability of the housewife; obviously the more conscientious she is in grinding, winnowing and sifting, the more inferior will the product be nutritionally.

No attempt has been made to study the nicotinic-acid content in these grains, in view of the bound nature of this vitamin in most cereals (Chaudhuri \& Kodicek, 1950), and because it appears unlikely that the processing will cause any appreciable release of the vitamin. It is, however, proposed to investigate the availability of nicotinic acid in the grains, in view of the relatively high incidence of pellagra in Southern Rhodesia.

\section{SUMMARY}

I. Traditional methods of grinding maize (Zea mays L.), sorghum (Sorghum vulgare Pers.), bulrush millet (Pennisetum typhoideum) and finger millet (Eleusine coracana) in Southern Rhodesia are described; the extraction rates were found to be about 55 , 66,75 and $80 \%$ respectively.

2. The proximate analyses and mineral, thiamine and riboflavin contents are reported for meals and offals of each grain, except finger millet for which figures for whole grain and meal are given.

3. Losses of about $90 \%$ of thiamine and riboflavin were found to occur from maize meal, with smaller losses of all other nutrients except carbohydrate. For sorghum and bulrush millet, the losses were smaller and for finger millet were negligible.

I acknowledge, with thanks, the permission from Dr W. Sheffield, Director of Medical Services (Southern Rhodesia), to publish this work.

\section{REFERENCES}

Association of Vitamin Chemists Inc. (195I). Methods of Analysis, 2nd ed. New York: Interscience Publishers.

Bandemer, S. L. \& Schaible, P. J. (1944). Industr. Engng Chem. (Anal.), 16, 3 7 .

Carr, W. R. (1956). Cent. Afr. F. Med. 2, 334.

Chaudhuri, D. K. \& Kodicek, E. (1950). Biochem. F. 47, xxxiv.

Ellis, R. T. (1959). E. Afr. agric. F. 24, 25 I.

Gehrke, C. W., Affsprung, H. E. \& Yung, C. L. (1954). Analyt. Chem. 26, r944.

Great Britain. Parliament (1932). The Fertilizers and Feeding Stuffs Regulations, I932. S.R.O. no. 658. Kent-Jones, D. W. \& Amos, A. J. (1947). Modern Cereal Chemistry, 4th ed. Liverpool: The Northern Publishing Co. Ltd.

Ridyard, H. N. (1949). Analyst, 74, I8.

Williamson, J. (I955). Useful Plants of Nyasaland. Zomba, Nyasaland: Government Printer. 